\title{
Arkadiusz Czarniakowski
}

Uniwersytet Ekonomiczny we Wrocławiu

e-mail: arkadiusz.czarniakowski@ue.wroc.pl

\section{ZAWÓD: TANCERKA/TANCERZ. IDENTYFIKACJA KLUCZOWYCH PROBLEMÓW Z PERSPEKTYWY BADAŃ WLASNYCH OCCUPATION DANCER. THE KEY ISSUES FROM THE PERSPECTIVE OF OWN RESEARCH}

DOI: $10.15611 /$ sie.2016.1.06

\begin{abstract}
Streszczenie: Artykuł porusza temat zawodu tancerki/tancerza w instytucjach kultury, takich jak teatry. Przedstawiono w nim zarys i specyfikę pracy wykonywanej przez tę grupę zawodową, jak również przeanalizowano ogólnie współczesny rynek artystyczny w Polsce. W artykule skupiono się m.in. na stylu zarządzania, work-life balance, problematyce zabezpieczenia społecznego oraz kulturze organizacyjnej. Przeprowadzono w tym celu wywiad indywidualny $\mathrm{z}$ etatowymi tancerzami jednego z wrocławskich teatrów. Zadaniem artykułu jest przede wszystkim próba opisu zawodu tancerza/tancerki oraz identyfikacja najważniejszych problemów związanych z jego wykonywaniem. Dodatkowym celem jest wstępna analiza literatury przedmiotu. Powodem, który skłonił autora do analizy tego zagadnienia, jest widoczny niedostatek opracowań dotyczących prezentowanego tematu w dotychczasowych opracowaniach literaturowych. Koncentracja omawianych zagadnień dotyczy ogólnie branży artystycznej, rzadko stricte tanecznej.
\end{abstract}

Slowa kluczowe: tancerze, rynek pracy artystów, zarządzanie w kulturze.

Summary: The article focuses on the professional dancers in cultural institutions such as theaters. The problem was presented in outline and specifics of the work done by this group, as well as generally considered contemporary art market in Poland. The article focuses, among others, on management style, work-life balance, issues of social security and organizational culture. The publication includes individual interviews with full-time dancers of one of the Wroclaw theaters. The aim of this publication is primarily an attempt to describe the dancers' profession and to identify the most important problems related to its execution. An additional objective of this article is to make an initial analysis of the literature. The reason which prompted the author to undertake such a purpose, is apparent paucity of studies in the existing literature. The concentration of the topics discussed relates generally to the creative industries, rarely strictly dance.

Keywords: dancers, artists market labor, management in culture. 
Arkadiusz Czarniakowski

Tak dtugo nie zrozumiesz sfery kultury i sztuki, jak dtugo nie pojmiesz, $\dot{z} e 1+1$ da ci w tej dziedzinie każda inna liczbę, ale nie dwa.

Pablo Picasso

\section{Wstęp}

Taniec w Polsce stał się bardziej popularny za sprawą wielu programów telewizyjnych z udziałem celebrytów, którzy promując tę gałąź sztuki, jednocześnie zaczęli dostarczać określonych wzorców, propagować wiedzę o technikach, różnorodności i rozpoznawalności stylów tańca. Wspomniane programy umożliwiły tancerzom z całego kraju zaistnienie w szerszym odbiorze społecznym i, co ważne, przyczyniły się do rozwoju tańca w Polsce oraz zwiększenia świadomości społeczeństwa, że jest to zawód równie poważny, jak każdy inny.

Tancerze zawodowi tworzą zazwyczaj tło różnym oprawom artystycznym, nie są najczęściej na pierwszym planie - chyba że jest to teatr tańca, w którym taniec jest głównym bohaterem. W świetle tak zarysowanego problemu należy zauważyć, że „Praca wykonywana przez nich nie może być opisana w kategoriach efektywności rynkowej, która zdominowała potransformacyjne myślenie o pracy jako takiej"1. Efektem pracy tancerzy są dobra niematerialne, które są trudne do wyceny i określenia ich użyteczności.

Problemem badawczym niniejszego artykułu będzie odpowiedź na pytanie, jakie czynniki stanowią największe wyzwania dla tancerza/tancerki podczas wykonywania zawodu. Dlatego też celem niniejszej publikacji jest próba opisu zawodu tancerza/tancerki oraz identyfikacja czynników stanowiących największy problem podczas wykonywania zawodu. Na potrzeby artykułu autor przeprowadził w marcu 2015 roku wywiad indywidualny z każdym etatowym tancerzem $(n=3)$ jednego z wrocławskich teatrów. Udzielający wywiadu odpowiadali na pytania odnoszące się do stylu kierowania i kultury organizacyjnej w ich instytucji. Ponadto poruszano tematy związane z work-life balance, dotyczące problematyki zabezpieczeń społecznych oraz innych problemów, które - według pytanych - doskwierają tej grupie zawodowej. W artykule kolejno będą poruszone zagadnienia: metody wykorzystanej w badaniu, opisu specyfiki pracy tancerki/tancerza oraz opisu rynku pracy, ekonomii i tematu zabezpieczeń społecznych w kulturze.

\section{Metoda badawcza}

Ze względu na to, że obiektem analizowanym i opisywanym na potrzeby niniejszego artykułu jest instytucja kultury, w której autor pracował przez siedem lat, możliwe było przeprowadzenie wspomnianego badania. $Z$ racji specyficznego tematu tej pu-

${ }^{1}$ http://iwanski.natemat.pl/15187,kaszel-artysty (23.12.2015). 
blikacji osobami uczestniczącymi w badaniu byli wszyscy etatowi tancerze tylko jednej wybranej instytucji kultury, ponieważ mogli oni wypowiedzieć się na temat tej konkretnej placówki i jej funkcjonowania (wielkość próby: $n=3$ ).

$\mathrm{W}$ celu wyjaśnienia problemu badawczego posłużono się następującymi metodami badawczymi: metodą indywidualnych przypadków, obserwacyjną oraz sondażem diagnostycznym.

Metoda indywidualnych przypadków jest „metodą (...) opierającą się na analizie konkretnych wyodrębnionych zdarzeń i osób. (...) Można nią badać style kierowania i kulturę organizacyjną"2.

Metoda obserwacyjna to „podstawowy sposób gromadzenia materiału badawczego przeznaczonego do opisu i klasyfikacji w celu poznania badanej rzeczywistości (...); fakty te ujmuje we wzajemnych związkach i zależnościach, z przyczynowo-skutkowymi włącznie"3.

Sondażem diagnostycznym zaś nazywamy ,przedsięwzięcie naukowe polegające na statystycznym gromadzeniu faktów i informacji o zjawiskach strukturalnych i funkcjonalnych oraz dynamice ich rozwoju" 4 .

W ramach wspomnianych metod wykorzystano techniki obserwacji uczestniczącej (z użyciem narzędzia w postaci arkusza obserwacji), wywiadu (z wykorzystaniem narzędzia w postaci kwestionariusza wywiadu). Wywiad polegał na pozyskiwaniu danych za pomocą bezpośredniej rozmowy ${ }^{5}$. Każdy z tancerzy został przebadany indywidualnie tą techniką badawczą, a samo badanie trwało około jednej godziny. Obserwacja uczestnicząca, definiowana jako ,proste spostrzeżenia jednostkowych faktów, zjawisk, osób lub przedmiotów w ściśle wyznaczonym czasie i miejscu" ", była techniką, którą autor publikacji uzupełniał zdobyte informacje.

W celu przeprowadzenia badania autor zastosował kwestionariusz wywiadu, w którym znalazło się 10 otwartych pytań, dotyczących opinii na temat branży tanecznej i specyfiki zawodu, motywowania i kierowania w instytucji kultury, panującej kultury organizacyjnej, ścieżki zawodowej, uczestnictwa w przemyśle kreatywnym oraz godzenia życia rodzinnego z zawodowym (work-life balance). Wypowiedzi uzyskane podczas wywiadu zostały wplecione w tekst artykułu.

\section{Specyfika pracy tancerki/tancerza}

Artystyczna działalność i system pracy w instytucjach kultury, takich jak teatry, opery itp., jest bardzo specyficzna i różna od innych grup zawodowych. Począwszy od systemu godzinowego, w którym pracuje się od wtorku do soboty, w godzinach 10.00-14.00 oraz 18.00-22.00. Na przykład administracja takich instytucji pracuje

\footnotetext{
2 J. Apanowicz, 2002, Metodologia ogólna, Wydawnictwo „Bernardinum”, Gdynia, s. 70.

3 Tamże, s. 62.

${ }^{4}$ Tamże, s. 70.

5 Tamże, s. 85.

${ }^{6}$ Tamże, s. 81.
} 
w standardowych godzinach, tj. 8.00-16.00, od poniedziałku do piątku; ten system dotyczy pracowników etatowych. Jako że głównym celem w instytucjach kultury, wystawiających sztuki performatywne, jest produkcja repertuarowych przedstawień, obowiązkiem tancerza/pracownika jest bycie $\mathrm{w}$ zakładzie pracy $\mathrm{w}$ godzinach ich wystawiania. Z reguły pokrywa to się z godzinami 18.00-22.00 i najczęściej od czwartku do niedzieli, a wolne dni oddawane są przy urlopie w okresie letnim, kiedy teatr nie wystawia spektakli przez prawie trzy miesiące.

W godzinach pracy, o których już wspominano, odbywają się np. prace bieżące, szkolenia, warsztaty i lekcje lub próby do aktualnych przedstawień czy premier. W przypadku tancerzy lekcje tańca są obowiązkowe i służą podtrzymaniu zdolności i jakości technik tańca oraz utrzymaniu dobrej kondycji. Tancerze z racji swojego specyficznego zawodu nieustannie rozwijają swoje umiejętności, wpływające na poziom produkcji teatralnej.

Analizując kulturę organizacyjną, styl zarządzania i relacje międzyludzkie w organizacji, jaką jest teatr, można wyszczególnić kilka charakterystycznych elementów. W zespole tanecznym - będącym składową całego zespołu teatralnego - można zaobserwować spłaszczoną strukturę organizacyjną. Polega ona na tym, że w relacji kierownik-artysta i artysta-artysta występują luźne, koleżeńskie stosunki, bez względu na wiek. Jedna osoba z zespołu tanecznego skomentowała to tak w wywiadzie przeprowadzonym przez autora: „Artyści mają kontakt z ciałem/cielesnością na scenie, także jest to normalne, że są tu bliższe relacje. (...) Współpraca i życie w zgodzie ze wszystkimi jest istotna, ponieważ widać takie rzeczy na scenie. Przykładowo, jeśli artyści nie mają do siebie zaufania, to odbije się to na jakości przedstawienia i zauważy się pewien fałsz (...). Bardzo pozytywnym zjawiskiem jest pomaganie sobie i proponowanie rozwiązań, a nie wytykanie sobie błędów. Takie rzeczy wpływają na przyjemną współpracę" 7 .

Co ciekawe, ta wypowiedź stoi w opozycji do opinii zamieszczonej w projekcie pod redakcją Agnieszki Stęplewskiej, w którym to uznaje się, że powinien być dystans w relacji między kierownikiem (dyrektorem) a pracownikiem teatru8.

Kolejną kwestią wartą poruszenia jest kreatywność tancerzy. Praca tancerki/ tancerza jest zawodem, w której kreatywność i jej rozwijanie napędzają i motywują do jeszcze większej i lepszej pracy (też twórczej). Gdy zespół jest praktycznie tylko odtwórczy, a nie twórczy, wówczas kreatywność nie musi być potęgowana, jednakże, by warunki sprzyjały rozwojowi tych cech, muszą być zagwarantowane odpowiednia atmosfera i reżim pracy oraz dobre relacje $z$ kierownikiem. Wypowiedź członka zespołu tanecznego na ten temat brzmiała następująco: „Od kierownika zespołu tanecznego może wiele zależeć. Przykładowo na lekcjach dla tancerzy daje zadania improwizacyjne, poprawiające świadomość ciała, dzięki temu bardziej an-

\footnotetext{
${ }^{7}$ Opinia uzyskana podczas badania własnego.

${ }^{8}$ A. Stęplewska (red.), 2011, Kultura lokalnie. Między uczestnictwem w kulturze a partycypacja w zarządzaniu, Wydawnictwo MIK, Kraków, s. 50-51.
} 
gażuje i motywuje do pracy, a również obustronnie wymieniamy się doświadczeniem (...). Kierownik dobrze by był wyważony - bez »tyranii«, ale by potrafił prowadzić po partnersku grupę - dzięki temu, zdobywa powagę i zaufanie podwładnych. Spotkać można kierownictwo zamknięte, z którym trudno się dogadać, a w specyfice tej pracy nie jest to dobra strategia" ${ }^{9}$. Innymi słowy, komunikacja i wymiana informacji, owszem, przebiega dwustronnie, ale ostatecznie kierownik jest autokratą i podejmuje decyzje. A.C. Lindgren pisze: „W zespole tanecznym (tu baletowym) nie może być demokracji”"

Praca tancerki lub tancerza rzadko zamyka się w murach instytucji, w której są oni zatrudnieni. Wiąże się to $\mathrm{z}$ przeciętnymi wynagrodzeniami, a wręcz mówi się o głodowych wynagrodzeniach" ". Pracują oni najczęściej jako instruktorzy tańca lub prowadzący warsztaty taneczne czy jurorzy na turniejach tańca. Zdarza się, że biorą udział w spektaklach i projektach zewnętrznych - często bezpłatnych. Uczestniczą w tych nieodpłatnych projektach, uzasadniając to możliwością poznania szerzej środowiska tanecznego, nowymi doznaniami artystycznymi oraz ambitnością przedsięwzięcia. Warto wspomnieć w tym miejscu, że praca artystyczna oparta jest na pracy i zarządzaniu projektami, ponieważ każde przedstawienie jest swojego rodzaju projektem. W publikacji pod redakcją A. Stęplewskiej wspomina się, że „Należy uznać, że kierunek »ku organizacji projektowej« wydaje się właściwą drogą zmiany struktur organizacyjnych i szerzej - metod zarządzania instytucjami kultury, co w przyszłości ma szansę zaowocować szerszym i skuteczniejszym wykorzystywaniem instrumentów partycypacyjnego zarządzania"12.

Wśród artystów - w tym i tancerzy - częste jest zjawisko przyjmowania tzw. jobów, czyli chałtur, które może nie mają dużego nasycenia artystycznego, ale za to są dobrze płatne i nie pochłaniają za dużo czasu na przygotowanie. To, ile i czy tancerz pracuje więcej niż na etacie, jest uzależnione od statusu i zapotrzebowania finansowego, jakie chce osiągnąć, np. przez powstawanie dodatkowych wydatków na dzieci. Jedna $\mathrm{z}$ wypowiedzi przebadanych tancerzy w tej sprawie brzmiała następująco: „Niekiedy zdarza się taka szczęśliwa sytuacja dla tancerza, że taniec przychodzi do niego, a on w to wchodzi"13.

Jeśli tancerze są zatrudnieni $\mathrm{w}$ instytucjach kultury na etat, to można mówić o ich wielkim szczęściu, bo na całym świecie dąży się do maksymalnej deetatyzacji tego typu instytucji ${ }^{14}$. Etat daje poczucie bezpieczeństwa zawiązane z zabezpieczeniem socjalnym (ubezpieczeniem zdrowotnym i rentowo-emerytalnym). W tym

9 Opinia uzyskana podczas badania własnego.

${ }^{10}$ A.C. Lindgren, 2009, The National Ballet of Canada and the Kimberly Glasco Legal Arbitration Case, The Journal of Arts Management, Law and Society, vol. 39, no. 2, s. 13.

${ }^{11}$ A. Stęplewska (red.), wyd. cyt., s. 55.

12 Tamże, s. 153-154.

${ }_{13}$ Opinia uzyskana podczas badania własnego.

${ }^{14}$ A. Czarniakowski, 2013, Public Relations w marketingu kultury na podstawie Teatru Muzycznego CAPITOL, Praca magisterska, Wrocław, s. 10. 
kontekście ciekawym spostrzeżeniem, odnoszącym się do samej twórczości, podzielił się tancerz podczas wywiadu, stwierdzając: „Etat poniekąd rozleniwia, bo nie generujemy sobie sami pracy (w tym twórczej), tylko wykonujemy plan instytucji, w której pracujemy"15.

Aktualnie tancerze nie mają wielu przywilejów, jak przed laty. Do niedawna był to zawód, który po 15 latach udokumentowanej pracy gwarantował przejście na wcześniejszą emeryturę. W tej chwili tancerze muszą pracować do 65. (kobiety) lub 67. (mężczyźni) roku życia. Tańczenie zawodowe do późnego wieku jest praktycznie niemożliwe. Niewielu jest tancerzy teatrów tańca, którzy mogą pracować do tak późnej emerytury. Są, oczywiście, artyści, których kariery przeczą temu stwierdzeniu, jednak są to absolutne wyjątki. Przykładem może być wielka artystka Pina Bausch, która tańczyła praktycznie do śmierci. W takich zespołach nie fizyczność, a przekaz jest najczęściej ważniejszy. Scena ma jednak swoje wymogi - np. poprzez estetykę ciała, a starość nie jest w tym pomocna. Oczywiście, po ukończeniu aktywności zawodowej, jaką jest bycie tancerzem, można nadal być blisko tańca, np. jako choreograf, instruktor, teoretyk tańca, jednakże rynek jest ograniczony.

Udogodnieniem dla tancerzy jest aktualnie jedynie emerytura pomostowa, która: „(...) przysługuje osobom, które wykonywały pracę w szczególnych warunkach (...), które w pełnym wymiarze czasu pracy są zatrudnione przy pracach w szczególnych warunkach. Pracownikami takimi są zgodnie z ustawą tancerze zawodowi, ubezpieczeni z tytułu działalności artystycznej. Ich praca wymaga szczególnej odpowiedzialności oraz szczególnej sprawności psychofizycznej, których możliwość należytego wykonywania w sposób niezagrażający bezpieczeństwu publicznemu, w tym zdrowiu lub życiu innych osób, zmniejsza się przed osiągnięciem wieku emerytalnego na skutek pogorszenia tej sprawności”"16.

Praca tancerza jest bardzo wymagającym, fizycznym zawodem; jest ciągłą pracą $\mathrm{z}$ ciałem.

Jak wynika z badań przeprowadzonych przez autora: „Każdy artysta musi włożyć duży wysiłek fizyczny, aby być dobrym w tym, co robi, np. muzycy instrumentów dętych grający na swoich instrumentach, aktorzy z umiejętnością wejścia z jednej emocji w drugą, no i my, gdzie nasze ciało, to nasz warsztat pracy"17.

Wśród tancerzy, którzy zdecydowali się żyć z tańca, można zauważyć pewien trend: każdy z tancerzy był związany z tańcem od dziecka. W późniejszym okresie część badanych była wciąż wychowankami swoich instruktorów tańca/szkół tańca/teatrów tańca, a część kończyła szkoły artystyczne (liceum, studia, studium) lub powiązane z tańcem w jakiś sposób, jednak najczęściej nie było to ich jedyne wykształcenie, jakie zdobyli. Raport z badań pod redakcją D. Ilczuk potwierdza taki stan rzeczy ${ }^{18}$.

15 Opinia uzyskana podczas badania własnego.

16 http://www.zus.pl/default.asp?p=4\&id=392 (23.12.2015).

17 Opinia uzyskana podczas badania własnego.

18 D. Ilczuk (red.) 2013, Rynek pracy artystów i twórców w Polsce. Raport z badań, BydgoszczWarszawa, s. 92. 
Przebadani w nich tancerze nie byli członkami żadnych stowarzyszeń związanych pośrednio lub bezpośrednio z ich branżą, np. ZASP, PTT itp., ponieważ nie widzieli $\mathrm{w}$ tym żadnych profitów ${ }^{19}$. Co ciekawe, ogólnie artyści to indywidualiści, ale z reguły bierni w walce o swoje interesy.

Osoby znające realia oraz wady zawodu artysty wybierają go przede wszystkim dlatego, że praca jest zgodna z zainteresowaniami artysty i pozwala realizować oraz poszerzać zainteresowania pozazawodowe ${ }^{20}$.

Praca tancerza jest niewątpliwie trudnym zawodem. Jak więc wygląda work-life balance w tym zawodzie? Można mieć bardzo duży podziw dla rodzin tancerzy (i innych zawodów artystycznych) z dziećmi, ponieważ system pracy w godzinach 10.00-14.00 i 18.00-22.00 nie sprzyja opiece nad dziećmi i ich wychowywaniu. Okres przedpremierowy jest najtrudniejszy dla życia rodzinnego. Dodatkowo dla kobiet tancerek zajście w ciążę jest wyłączeniem z rynku pracy na dłuższy czas.

Praca tancerza nie ogranicza się tylko do miejsca pracy, istnieje także poza nim. Mówi się wtedy o tzw. umiarkowanej pracy myślami po godzinach. Prywatne problemy życiowe tancerzy też wpływają na jakość ich pracy. Wtedy pomaga wsparcie (w tym emocjonalne) znajomych, rodziny oraz środowiska, w którym pracują. Badani na potrzeby tego artykułu tancerze wspominają, iż czują duże wsparcie wśród współpracowników. Komentarz jednego z tancerzy, dotyczący tej kwestii, jest następujący: „Odprężenie od pracy daje również spotkanie z osobami nie z branży (znajomi etc.), z którymi można porozmawiać. Daje to możliwość zastanowienia się, na ile problemy w naszym zawodzie są podobne lub różnią się od innych branż”21.

Niejednokrotnie doba jest za krótka w pracy tancerza; i nie chodzi tylko o życie rodzinne, które jest okrojone, lecz o zwykłe zregenerowanie ciała. Bardzo często brakuje czasu na odpoczynek, co może skutkować kontuzjami. Pod tym względem tancerz, od którego wymaga się dodatkowo gry aktorskiej oraz estetyki ruchu, jest jak sportowiec - potrzebuje takiej samej odnowy i ewentualnie rehabilitacji.

Instytucje zatrudniające tancerzy powinny poważnie pomyśleć nad zatrudnieniem lub udostępnieniem bezpłatnych dla tancerzy wizyt okresowych u lekarza medycyny sportowej oraz dietetyka. Takie działania wpłyną na sprawność i jak najdłuższe bycie w zawodzie, lepszą regenerację, uświadamianie i edukację tancerzy. Dzięki tym osobom można wyeliminować błędy żywieniowe oraz błędy popełniane podczas motoryki ruchu czy rozgrzewce, m.in. dlatego dobrym pomysłem jest prowadzenie dla tancerzy zajęć z technik somaestetycznych, jak m.in. Body Mind Centering (BMC®), Feldenkrais itp. Coraz więcej miejsc pracy - również instytucja, w której przeprowadzono wywiad z tancerzami - prowadzi karty, dzięki którym można wejść, za małą miesięczną opłatą, do wielu miejsc sportowo-rekreacyjnych. Tym

19 Opinia uzyskana podczas badania własnego.

20 T.M. Dudzik, D. Ilczuk, 2013, SOSART. Badanie rynku pracy artystów i twórców w Polsce, Warszawa, s. 81.

${ }^{21}$ Opinia uzyskana podczas badania własnego. 
sposobem można zadbać w pewnym stopniu o swój czas na regenerację. Jest to ważne, ponieważ dobry spektakl może być zagrany, jeśli mamy artystów w szeroko rozumianej dobrej formie, a dobrego spektaklu oczekuje widz.

Warunki pracy są też istotnym elementem pracy tancerza. Przykładowo projektowane sale, na których godzinami spędzają tancerze, powinny być konsultowane właśnie z tą grupa zawodową. Chodzi tu o ergonomię przestrzeni, odpowiedni materiał podłoża, drążki, lustra na odpowiednich ścianach, temperaturę panującą w sali - te wszystkie czynniki wpływają na komfort i higienę pracy tancerza. Sytuacja bywa różna ze względów ekonomicznych instytucji oraz różnego poziomu wiedzy osób projektujących sale.

Wszystkie wymienione czynniki wpływają poniekąd na pojawienie się (lub nie) wypalenia zawodowego. Wypalenie zawodowe wśród tancerzy może wystąpić w momencie, gdy nie czuje się dalszego rozwoju i poznawania czegoś nowego w tańcu. Zjawisko wypalenia zawodowego jest również utożsamiane przez tancerzy $\mathrm{z}$ brakiem zdrowia, tzw. wypaleniem ciała. Powszechne są opinie, że szkoły baletowe mogą ,wypalić” tancerzy: część pasji znika po ukończeniu szkoły, a w tym zawodzie pasja jest kluczowa ${ }^{22}$. Zawód tancerza jest zatem mocno narażony na wypalenie zawodowe ${ }^{23}$.

\section{Rynek pracy, ekonomia i zabezpieczenia społeczne w kulturze}

Przedstawiona we wcześniejszym punkcie specyfika zawodu tancerki/tancerza nie wyczerpuje wszystkich problemów związanych z tym zawodem. Dodatkowe czynniki determinujące wykonywanie tej pracy mają swoje źródło w gospodarce i przyjętym porząaku politycznym danego kraju. Dlatego też istotne wydaje się omówienie zagadnień, takich jak rynek pracy, ekonomia i zabezpieczenia społeczne w kulturze.

Na wstępie należałoby jednak wyjaśnić kilka terminów, m.in. rynek pracy, popyt i podaż na rynku pracy. Po pierwsze, pojęcie rynku pracy będzie rozumiane jako „miejsce konfrontacji podaży pracy, zgłaszanej przez osoby aktywne zawodowo i popytu na siłę roboczą, zgłaszanego przez przedsiębiorstwa"24. W tej publikacji termin „przedsiębiorstwa” zastąpiony będzie określeniem ,instytucje kultury”. Popyt definiowany będzie jako zapotrzebowanie na siłę pracowniczą - tancerzy - natomiast podażą nazwiemy ilość pracy oferowanej przez instytucje kultury.

Publikacja T. Dudzik i D. Ilczuk dobrze opisuje rzeczywistość rynku pracy artystów: „Wielkość popytu na rynku pracy artystów zależy od gotowości do uczestnictwa w życiu kulturalnym (finansowanego ze źródeł prywatnych obywateli) oraz stopnia zaangażowania państwa $\mathrm{w}$ finansowanie »zbiorowej konsumpcji« dóbr kultury. Powszechne jest też oczekiwanie, że nowym sposobem tworzenia miejsc pracy

22 Taki wniosek wyciągnięto na podstawie badań własnych autora.

${ }^{23} \mathrm{http}: / /$ iwanski.natemat.pl/15187,kaszel-artysty (23.12.2015).

${ }^{24}$ O. Kowalczyk, S. Kamiński (red.), 2013, Wymiary polityki społecznej, Wydawnictwo Uniwersytetu Ekonomicznego we Wrocławiu, Wrocław, s. 172. 
dla artystów staje się sektor kreatywny. Warto w tym miejscu podkreślić, że celem polityki kulturalnej państwa jest oddziaływanie nie tylko na stronę popytową rynku. Poprzez pośrednie i bezpośrednie sposoby finansowania samych artystów i infrastruktury ma miejsce ingerencja państwa po stronie podażowej rynku"25.

Wspomniany sektor kreatywny staje się nowym mikrorynkiem (pracy) kultury, na którym coraz chętniej i więcej artystów (w tym tancerzy) znajduje zatrudnienie, najczęściej na umowę o dzieło lub zlecenie. Wydaje się, że sektor kreatywny może stać się wiodącym rynkiem pracy artystów, ponieważ rozwija się w szybkim tempie, a jest to miejsce, gdzie spotyka się ekonomia $\mathrm{z}$ kulturą ${ }^{26}$. Przemysł kreatywny daje możliwości - prócz zarobku - zaistnienia i bycia rozpoznawalnym artystą.

Pełne zastosowanie rozwiązań wolnorynkowych w kulturze nie przyniesie dobrych wyników, kultura nie powinna być całkowicie skomercjalizowana, a interwencja państwa jest konieczna ${ }^{27}$. Rozwiązania takie mogą powodować kierowanie się głównie rachunkiem ekonomicznym, co w konsekwencji prowadzi do deetatyzacji, stosowania outsourcingu wielu działów w instytucjach kultury ${ }^{28}$. W takim wypadku swoboda artystyczna jest mocno thumiona.

Wejście na rynek pracy w sektorze kultury jest trudne, gdyż jest to dość hermetyczny rynek. Wejście w niego determinują na ogół trzy czynniki: talent, szczęście i niejednokrotnie znajomości. W tej grupie zawodowej selekcja dokonuje się w sposób niezwykle bezwzględny ${ }^{29}$.

Polityka kulturalna państwa po roku 1989 poddała kulturę działaniom wolnego rynku. Cytując A. Wąsowską-Pawlik, można to ująć następująco: „W jakimś sensie kultura w Polsce do dziś płaci za ówczesne decyzje marginalizacją, i to zarówno w wymiarze symbolicznym, jak i finansowym" 30 . Dlatego właśnie najczęstsze cięcia finansowe odbywają się m.in. w sektorze kultury. Polityka kulturalna ma decydujący wpływ na rozwój kultury w kraju i - ponownie przytaczając A. Wąsowską-Pawlik - „Właściwe ramy prawne dla funkcjonowania twórców i instytucji, zapewnienie odpowiedniego finansowania dostępnego zarówno dla publicznych, jak i dla niepublicznych podmiotów, dążenie do odpolitycznienia decyzji finansowych i merytorycznych na różnych szczeblach - to pożądane elementy polityki kulturalnej, za którą odpowiada państwo"31. Dlatego państwo ponosi odpowiedzialność za warunki, w jakich sztuka jest realizowana.

Niepokojący jest wynik raportu nt. monitoringu rynku pracy artystów, w którym czytamy: „Rynek pracy artystów w Polsce jest w niewystarczający sposób monito-

${ }_{25}$ T.M. Dudzik, D. Ilczuk., wyd. cyt., s. 134.

26 J. Głowacki, 2013, Przemysty kreatywne i ich wptyw na gospodarke, Narodowe Centrum Kultury, Warszawa, s. 435.

${ }^{27}$ D. Ilczuk (red.), wyd. cyt., s. 47.

${ }^{28}$ Uniwersytet Ekonomiczny w Krakowie, Małopolska Szkoła Administracji Publicznej, 2009, Finansowanie kultury i zarządzanie instytucjami kultury, Kraków, s. 40.

${ }^{29} \mathrm{http}: / /$ iwanski.natemat.pl/15187,kaszel-artysty (23.12.2015).

${ }^{30}$ A. Wąsowska-Pawlik, 2013, Polityka kulturalna Polski 1989-2012, Narodowe Centrum Kultury, Warszawa, s. 113.

31 Tamże, s. 121-123. 
rowany i analizowany (...). Za granicą artysta na rynku pracy jest przedmiotem zainteresowania i urzędów statystycznych, i ośrodków naukowych wspieranych finansowo przez rządy i samorządy. W Polsce tak nie jest. I nie bardzo wiadomo, dlaczego (...) aż 63\% respondentów (...) ocenia źle i bardzo źle wsparcie ze strony państwa dla artystów"32.

Francuski kompozytor i artysta Serge Gainsbourg w jednym ze swoich wywiadów powiedział: „W 1945 roku obwieściłem zamiar poświęcenia życia sztuce”. W branży sztuki i kultury sformułowanie ,„poświęcenie” jest bardzo adekwatne.

Od wielu lat sektor kultury i sztuki jest najsłabiej opłacaną branżą. Tabela 1 ukazuje, jaka jest relacja wynagrodzenia w kulturze i sztuce $\mathrm{z}$ wynagrodzeniami w innych branżach. Tylko nieliczna grupa artystów zarabia spore sumy i zdarza się również, że na niektóre przedsięwzięcia idą spore fundusze, niewarte tej ceny. W pracy T. Dudzik i D. Ilczuk czytamy: „Przychody artystów budzą szczególne emocje w kontekście zarobków czy może lepiej »niezarobków«, »pracy bez pieniędzy«, która to kwestia była źródłem fali protestów środowiska nie tylko w Polsce”. Grupa zawodowa tancerzy, której dotyczy publikacja, osiąga średni przychód roczny na poziomie 28333,83 zł3 . Odnosząc się do wypowiedzi jednego z tancerzy, można przytoczyć cytat: „Dla tancerzy pieniądz jest środkiem, a nie celem pracy, dlatego muszą mieć dużą determinację, by być tancerzami" 34 .

Trudności finansowe mogą pojawiać się w okresie wakacyjno-urlopowym, w którym wypłacana jest tylko podstawa, ponieważ w tym czasie nie ma repertuarowych przedstawień. Wielu tancerzy stara się o pracę jako instruktor tańca na wyjazdach letnich w ramach czasu urlopowego, który jest im zwracany w lipcu i sierpniu.

Tabela 1. Wynagrodzenia w wybranych branżach (brutto w zł)

\begin{tabular}{|l|c|c|c|c|}
\hline \multicolumn{1}{|c|}{ Branża } & Próba & 25\% zarabia mniej & Mediana & 25\% zarabia więcej \\
\hline IT & 11616 & 4000 & 6000 & 9200 \\
\hline Bankowość & 5811 & 3550 & 5500 & 9200 \\
\hline Telekomunikacja & 3003 & 3206 & 5500 & 9000 \\
\hline Ubezpieczenia & 1640 & 3100 & 5000 & 8625 \\
\hline$\ldots$ & & & & \\
\hline Ochrona środowiska & 1093 & 2600 & 3700 & 5975 \\
\hline Nauka, szkolnictwo & 5264 & 2500 & 3300 & 4500 \\
\hline Sektor publiczny & 4560 & 2500 & 3258 & 4600 \\
\hline Służba zdrowia & 5437 & 2350 & 3200 & 5000 \\
\hline Usługi dla ludności & 6988 & 2200 & 3000 & 4650 \\
\hline Kultura i sztuka & 1033 & 2210 & 3000 & 4080 \\
\hline
\end{tabular}

Źródło: Ogólnopolskie Badanie Wynagrodzeń (OBW) przeprowadzone przez Sedlak \& Sedlak w 2014 roku.

\footnotetext{
32 T.M. Dudzik, D. Ilczuk, wyd. cyt., s. 134.

33 D. Ilczuk (red.), wyd. cyt., s. 110.

34 Opinia uzyskana podczas badania własnego.
} 
Niskie wynagrodzenia w omawianej branży wynikają z wielu czynników. Z jednej strony artyści są skłonni pracować za niskie lub zerowe wynagrodzenie po to, by zaistnieć na rynku (debiutujący artyści) lub by z niego nie wypaść ${ }^{35}$. Interesujące jest to, jakie podejście i postawy dominują w społeczeństwie. Oto wypowiedź obrazująca tę sytuację: „Społeczeństwu - a dokładniej kontraktującym, do swoich wydarzeń artystyczno-rozrywkowych wydaje się często, że - przykładowo - przepłacają, płacąc, w ich mniemaniu, wysokie stawki, jakie sobie życzymy za występ pięciominutowy lub dwugodzinny koncert. Myślenie wtedy jest takie, że chcemy kwotę, na którą inne grupy zawodowe muszą pracować czasem cały dzień. Prawda jest taka, że nie opłacamy tych pięciu minut lub dwóch godzin pracy, tylko płacimy za wieloletni wkład artysty w swój warsztat, za który sam ponosił duże koszty w przeszłości, by osiągnąć jakość i poziom, jaki ma"36.

Można powiedzieć, że stawka jest rekompensatą kosztów poniesionych przez artystę, powinny się zwrócić w czasie.

Wielu jest twórców, którzy mają bardzo ciekawe pomysły na realizację swoich projektów, jednak główną barierą jest brak funduszy na te przedsięwzięcia. Uzyskanie mecenatu lub sponsora jest trudnym zadaniem, w szczególności, jeśli się jest indywidualnym tancerzem lub małym teatrem tańca. Źródłem środków, które mogą posłużyć na działalność artystyczną, jest Unia Europejska ${ }^{37}$. Niestety, niewiedza na temat istnienia takich funduszy, grantów czy stypendiów jest ogromna. Dodatkowo wymogi, które trzeba spełnić i mechanizmy przyznawania środków, są dość skomplikowane ${ }^{38}$.

Najwięcej tancerzy w Polsce pracuje na umowy-zlecenia lub umowy o dzieło. Bardzo nieliczna grupa tancerzy jest zatrudniona na umowę o pracę. Etatowi tancerze mają lepszą sytuację składkową od „zleceniowców”. W marcu 2015 roku Związek Zawodowy Twórców Kultury skierował do prezydenta Polski list otwarty w sprawie uregulowania kwestii ubezpieczeń społecznych artystów ${ }^{39}$.

Dobrym pomysłem dotyczącym artystów byłby fundusz artystyczny, działający jak KRUS, dzięki któremu artyści mogliby mieć pełne ubezpieczenie społeczne. Propozycja powstania tego funduszu padała wielokrotnie. Fundusz kościelny jest przykładem potwierdzającym, że państwo jest w stanie pokryć wszystkie koszty ubezpieczenia społecznego dużo większej grupy zawodowej od tancerzy ${ }^{40}$. Mowa jest także o powiązaniu sukcesów artystycznych z minimalnym zabezpieczeniem socjalnym oraz perspektywą na świadczenie emerytalne ${ }^{41}$.

Prawdopodobnie, gdyby samozatrudnienie w branży artystycznej było bardziej opłacalne dla samego zainteresowanego, dając mu wiele ulg, być może rozwiązało-

\footnotetext{
${ }^{35}$ D. Ilczuk (red.), wyd. cyt., s. 207.

${ }^{36}$ Opinia uzyskana podczas badania własnego.

${ }^{37}$ Ilczuk D. (red.), wyd. cyt., s. 149.

38 Tamże, s. 150.

${ }^{39} \mathrm{http}: / /$ www.obieg.pl/teksty/24326 (23.12.2015).

${ }^{40}$ D. Ilczuk (red.), wyd. cyt., s. 72.

${ }^{41} \mathrm{http} / / /$ iwanski.natemat.pl/15187,kaszel-artysty (23.12.2015).
} 
by to problem opłacania składek na ubezpieczenia społeczne. Na świecie istnieją udogodnienia dla samozatrudnionych artystów. Przykładem jest Kanada, w której jest możliwość odliczania uzasadnionych wydatków biznesowych, wliczając w to składki ubezpieczeniowe, instrumentów muzycznych i sprzętu, kosztów napraw sprzętu i wyposażenia, opłat prawnych i księgowych, profesjonalnych składek członkowskich, wydatków reklamowych, kosztów transportu związanych z pracą, kosztów lekcji muzyki, tańca, aktorstwa lub innych lekcji, poniesionych do określonej roli scenicznej lub w celu ogólnego samodoskonalenia się w indywidualnej artystycznej dziedzinie ${ }^{42}$.

\section{Zakończenie}

Artykuł miał na celu przedstawić zarys i specyfikę pracy wykonywanej przez branżę taneczną, z której wynika, że jest to zawód wymagający, fizyczny (jak u zawodowych sportowców), niesprzyjający życiu rodzinnemu, posiadaniu potomstwa oraz słabo opłacany. Tancerze zatrudniają się dodatkowo jako instruktorzy tańca w celu polepszenia swojej kondycji finansowej, ale również w celu rozwijania się jako pedagog tańca. Organizacyjnie jest to zawód z nietypowym godzinowym systemem pracy (10.00-14.00 i 18.00-22.00), ze spłaszczoną strukturą kultury organizacyjnej i z autokratycznym kierownictwem. W gruncie rzeczy tę ścieżkę zawodową obierają często tylko pasjonaci tańca. Rynek pracy tancerzy jest hermetyczny, mały, bezwzględny i trudny do wejścia, dlatego przemysł kreatywny staje się coraz częściej alternatywnym rynkiem pracy dla tej branży. Obecnie ingerencja i monitoring sektora tanecznego przede wszystkim przez urzędy państwowe są niewystarczające.

W publikacji przedstawiono przykłady sposobów niwelowania istniejących mankamentów zawodu tancerki/tancerza, np. powołanie funduszu artystycznego przypominającego w swoim działaniu KRUS, powiązanie sukcesów artystycznych z zabezpieczeniem socjalnym, powrót do wcześniejszych emerytur, obowiązek pracodawcy do użycia wszelkich dostępnych środków, do opieki i utrzymania tancerza w dobrej kondycji zdrowotnej, a także odliczanie uzasadnionych wydatków biznesowych.

Podkreślono również znaczenie warunków ergonomicznych pracy, których tancerze potrzebują do bezkontuzyjnej i zdrowej pracy artystycznej.

W celu ukazania bieżących problemów zawodu tancerki/tancerza autor posiłkował się swoimi doświadczeniami z prowadzonych badań. Mankamentem analizy może być dość mała próba badawcza $(n=3)$, skupiona na etatowych tancerzach tylko jednej performatywnej instytucji kultury. Intencją autora było jednak zasygnalizowanie omawianego problemu, który może być pogłębiony w toku dalszych prac badawczych na większej populacji i w różnych placówkach teatralno-operowych.

${ }^{42}$ D. Ilczuk (red.), wyd. cyt., s. 63. 


\section{Literatura}

Apanowicz J., 2002, Metodologia ogólna, Wydawnictwo „Bernardinum”, Gdynia.

Czarniakowski A., 2013, Public Relations w marketingu kultury na podstawie Teatru Muzycznego CAPITOL, praca magisterska, Wrocław.

Dudzik T.M., Ilczuk D., 2013, SOSART. Badanie rynku pracy artystów i twórców w Polsce, Warszawa.

Głowacki J., 2013, Przemysty kreatywne i ich wptyw na gospodarke, Narodowe Centrum Kultury, Warszawa.

http://iwanski.natemat.pl/15187,kaszel-artysty (23.12.2015).

http://natemat.pl/129143, dno-dna-czyli-zarobki-w-kulturze-i-sztuce-uciekaj-poki-mozesz-albobedziesz-pracowal-za-pol-darmo (23.12.2015).

http://www.lex.pl/akt/-/akt/dz-u-2008-237-1656 (23.12.2015).

http://www.obieg.pl/teksty/24326 (23.12.2015).

http://www.zus.pl/default.asp?p=4\&id=392 (23.12.2015).

Ilczuk D. (red.), 2013, Rynek pracy artystów i twórców w Polsce. Raport z badań, Bydgoszcz - Warszawa.

Kowalczyk O., Kamiński S. (red.), 2013, Wymiary polityki społecznej, Wydawnictwo Uniwersytetu Ekonomicznego we Wrocławiu, Wrocław.

Lindgren A.C., 2009, The National Ballet of Canada and the Kimberly Glasco Legal Arbitration Case, The Journal of Arts Management, Law and Society, vol. 39, no. 2.

Stęplewska A. (red.), 2011, Kultura lokalnie. Między uczestnictwem w kulturze a partycypacją w zarzadzaniu, Wydawnictwo MIK, Kraków.

Uniwersytet Ekonomiczny w Krakowie, Małopolska Szkoła Administracji Publicznej, 2009, Finansowanie kultury i zarządzanie instytucjami kultury, Kraków.

Wąsowska-Pawlik A., 2013, Polityka kulturalna Polski 1989-2012, Narodowe Centrum Kultury, Warszawa. 